\title{
Tenth Annual Meeting of the American Council for the Study of Islamic Societies
}

\author{
11 - 12 Ramadān 1413 / 5 - 6 March 1993 \\ Gcorgetown University, Washington, DC
}

The general theme, "Islam and Muslim Issues around the World," was discussed in six two-hour sessions. After the welcome address by Michael Bishku, the conference coordinator, the first session began with discussion on "Nationalism in the Balkans." Pet ya Nitzova presented a paper on the

Muslims of Bulgaria. Nedzib Sacimey outlined the historical causes of the problems of Bosnian Muslims and said that what is now happening in Bosnia is a preplanned anti-Muslim policy dating back to 1917. Edward Damich (George Mason University, Fairfax, VA), who focused on the Croats, disagreed. Both papers generated a heated debate. 
"Islam in the Arab World" was the topic of the second session. David Commins (Dickinson College, Carlisle, PA) talked about the Muslim Brothers and Egyptian popular culture. He gave a historical account of how this movement was founded by Hasan al Bannã and how it incorporated and adapted elements of Egyptian culture, especially the Sufi culture, into its program. Ibrahim Abu Rabi ' (Hartford Seminary, West Hartford, CT) enlightened the audience with his presentation "Reading the Intellectual History of the Modern Arab World: The Islamic Factor." He explained how Islamic ideologies influenced the thoughts of some of Arab intellectuals, especially Sayyid Quțub.

The third session focused on Islam outside the Arab world. This was the first time that the Council accommodated discussion about Islam in Africa. Four papers were presented. First, Howard Fedespiel (Ohio State University, Columbus, $\mathrm{OH}$ ) discussed "The Continuing Importance of Fiqh in Contemporary Indonesian Islam." He concluded that Indonesians have been struggling for many centuries to interpret Islam in the Indonesian context with the result that Islamic law is bent to reflect local customs. Indonesian scholars believe strongly that modernization and Islamic law can be woven together and that both should be accommodated.

Yushau Sodiq (Texas Christian University, Forth Worth, TX) analyzed Muslim-Christian relations in Nigeria. He stated that although both groups compete seriously to win converts, they can still work together to avoid religious tension. He appealed to leaders of both religions to shelve their theological and ideological differences and cooperate in bringing peace to their people. Theodore P. Wright, Jr. (State University of New York, Albany, NY) informed the audience about the causes and impact of the religious conflict surrounding India's Babri Masjid. He presented the Muslim and Hindu rationales for claiming possession of the mosque and concluded that politics, as played by the government, was responsible for many of the resulting atrocities.

Jeffrey Lefebvre (University of Connecticut, Storrs, CT) questioned American intervention in Somalia. He argued that while Americans saw it as humanitarian, some Africans saw it as a neocolonial invasion. The aftermath of American aid, as well as the crushing and air-raiding endured by Somali civilians might confirm African fears that the American intervention was designed to colonize Somalia, for why should a country be forced to receive aid?

The fourth session was a roundtable discussion on "Economic Prospects for Central Asia and Azerbaijan." Two scheduled speakers did not come to the conference, which gave ample opportunity for the World Bank representative to elaborate upon the organization's attempts to help the former Soviet republics. He alluded to the fact that the lack of individual initiative and ignorance of how the private sector functions has led 
to many financial problems in Russia. When the government ended its control, things began to fall apart. As Russians are used to being led, he postulated that it would take a long time for them to adjust to democracy.

"Gender, Social Movements and Islam" was the focus of the fifth session. Mervat Hatem (Howard University, Washington, DC) spoke on "Gender and the Debate on Democratization in Egypt," and Carrie Rosefsky (Harvard University, Cambridge, MA) talked about "Popular Islamic Literature in Egypt." Rosefsky mentioned how Islamic idcas have spread and become part of Egyptian literature. In her opinion, these books are popular and the ideas therein are expressed in such a way that anyone can understand them. Lama Abu Odeh, in her "Post-Colonial Feminism and Veiling," analyzed why some Arab women have retumed to the veil, which they see as a sign of respect. Not only uneducated Muslims are doing this, as was the case before, for women are now using it as a method of identity and as a preventive measure against harassment. The discussion led to many questions and a long debate even after the session was over. Carolyn Fluehr Lobban's (Rhode Island College, Providence, RI) "The Islamic Threat and British Policy in Sudan" stressed how London saw the Mahdist movement as a threat to its rule in Sudan.

In general, the conference enabled many scholars from different disciplines to discuss and improve their understanding of the immediate problems facing Muslims around the world. Although many opinions were raised, no solutions were suggested, as that was not the main goal of the conference. At the end, the executive committee of the Council conducted its business meeting, discussed its progress, and began planning for the 1994 annual conference.

Yushau Sodiq

Texas Christian University Fort Worth, Texas 